\title{
ADMINISTERING SUSTAINABLE DEVELOPMENT: A CASE OF DEPOK CITY
}

\author{
Muh. Kadarisman \\ Faculty of Social and Political Sciences \\ Universitas Muhammadiyah Jakarta \\ Jakarta, Indonesia \\ Muh.kadarisman@umj.ac.id
}

\author{
Ismiyati \\ Faculty of Engineering \\ Universitas Muhammadiyah Jakarta \\ Jakarta, Indonesia \\ ismiyati@umj.ac.id
}

Abstract-How is the administration of sustainable development in Depok City? Using descriptive and qualitative design methods to understand the object research phenomenon holistically, process oriented, natural, and empirical (verstehen, emic, and etic perspective). The summary of research result is that the administration of sustainable development in Depok City has been formulated in short-term and long-term plan, and aims to create a just and prosperous society based on Pancasila and the 1945 Constitution, which is oriented by the National Long-Term Development 2005-2025. It takes a strong commitment from government officials in Depok City to formulate, execute, and evaluate the sustainable development policies. The implementation of administration in supporting sustainable development in Depok City has been quite effective and efficient, by considering natural aspects in all policies. Administration in sustainable development in Depok City is a development process that characterized in fulfilling the needs of present and future community, while observing and maintaining the balance between the natural environment and the educated environment so that the interaction and interdependence witihn the two remains in equal harmony.

Keywords-administration;

sustainable

\section{INTRODUCTION}

The essence of administration in sustainable development in Depok City is seen clearly in all development activities, which is never apart from the administration system. It is emphasized that sustainable development in Depok City is a new approach, as the correction of policies or development strategies which has done before, which only pursue the result of development that is enjoyed by the present generation. But, it lacks of or puts aside the goals and the sustainability of the life of future generation/long-term. Based on literature study, administration in this research means as a cooperation process in an effort to achieve certain goal, while the goal in administration in sustainable development is a successful development that has succeeded in gaining a sustainably prosperous society.

Thus, the role of administration in this research is a system which is used to fulfill such expected condition. The administration position in the process of sustainable development in Depok City indicates a very important role and cannot be separated from the process of sustainable development. The demand for sustainable development in Depok City is due to the awareness of the Government and the community. The government and the people of Depok City realize that although the economic development in Depok City has become a top priority and shows significant results, the impact on the success of the economic development has been neglected. Therefore, the supporting natural environment in Depok City is worrying. It causes more frequent 
flood, air pollution that has reached severe level as the impact of tremendous and congestion, hazardous and toxic waste, etc. So, the aspect of sustainable development needs to be deeply examined. This is also the reason why this research is conducted.

Information from Depok City Public Relations Division (2017) shows that the understanding of environmental aspect in sustainable development in Depok City is not only limited to the natural environment, but also to the social-economic environment that are all interrelated and mutually influential. In the administration context, the cooperation is carried out by the involved parties in the process of sustainable development in Depok City. They are the government of Depok City, the community, and the other stake holders. Nevertheless, the controller role in sustainable development is the government of Depok City. In this matter, the government of Depok City becomes the most highlighted party in the implementation of the administration development. The government of Depok City is carrying out the duty of cooperation to achieve the goal of sustainable development through the State Civil Apparatus.

In this research, the administrators are the government and the citizen of Depok City. The administration for sustainable development in Depok City describes a perfect relation. There is a close correlation between administration and sustainable development. Administration is needed in sustainable development in Depok City to arrange the sustainable development programs into a targeted organization. The effective administration becomes the main tool in the process of sustainable development in Depok City. The role of administration for sustainable development in Depok City is a relation that leads to economic context, while the administration requires development to manage the administration itself.

Therefore, the administration should be arranged in such a way, always be monitored, and be able to follow the update of Depok City. In this matter, a good administration will give a good result. Without the administration, the sustainable development in Depok City will not be possible to do. So does the otherwise, without a development in administration itself, the administration system would be stagnant or deviate from what it should be. Administration becomes the direction for sustainable development in Depok City. A successful or a failure of a development is measured by the quality of administration system. A good administration could create a successful and sustainable development. So, all the parties that involved in sustainable development in Depok City that create the administration system should realize their role in sustainable development process.

Related to this matter, Depok City Public Relation Division (2017) affirmed that according to the government of Depok City the State Civil Apparatus should learn, study, and examine the root of all implementation problems in the governmental task so that the solution can be found and be able to be applied in the their unit. Therefore, the State Civil Apparatus should be managed well. As from the community side, either individual or groups require awareness to participate actively in the development process. However, the reality in the field shows that those ideal things turned out to be not ideal. It means that the result of early observation in research field has found some administrative irregularities in sustainable development in Depok City.

\section{RESEARCH METHOD}

This research uses descriptive method in order to get empirical facts about the administration of sustainable development in Depok City. The proper interpretation of the data is conducted precisely and described accurately the nature and action from the group or individual phenomena in the empirical level. The design or approach used in this research is qualitative approach. It is to observe and capture the reality, and to examine individual and group behavior, and also the informant's experiences. According to Meleong (2006), qualitative research method is a research procedure which produces descriptive data in the form of written or oral data from the people and the observed behavior.

Another expert, Sugiyono (2017), emphasized that qualitative research preferably towards in guiding the arrangement of substantive theory based on data. Qualitative method is used to 
comprehend meaning of the data that seem related to the focus of the research about the administration of sustainable development in Depok City. Therefore, the qualitative approach in this research is a process to comprehend problems related to the focus of the research, based on the holistic description which is made by words and the report of the point of view of the informant in details. The data type in this research consists of: a. Primary Data, which includes 1) Observation result towards the focus of the research, including work behavior of the administrator of sustainable development in Depok City. 2) Direct interview with Key Informant (6 informants) and Supporting Informant (8 informants).

Some questions are submitted in the form of open questionnaire. But there are some questions that do not have to be asked because the answers are already revealed in other questions or it is revealed on the conversation indirectly when meeting with the informant in informal occasion. The record of the interview is done by using tape recorder, which is put openly and seen by the informant. In this research, the tool to record the data of the result of the interview is in the form of tape recorder. 3) Doing Focus Group Discussion (FGD) by discussing the focus of the research on two groups outside the informants, which consist of 3 experts in each group. 4) Triangulation. It is to crosscheck the data that are obtained from the informant with another informant and to compare the data of the result of the interview based on observation related to the focus of the research.

The next is b. Secondary Data that includes: 1) Literature. Reading orientation by reviewing literature about theories, thinking frameworks, and journals related to the focus of the research, words and actions, written source data, photos, and statistics. 2) Documentation study to obtain secondary data that are needed to support the research, including official documents and source from archives. The selection of the informant is done by purposive sampling. It is done by direct appointed towards the employees in Secretariat of government of Depok City; Administrative Assistant; Economic, Development, and Social Assistant; Department of Spatial Planning and Settlement; Development Planning Agency at Sub-
National Level; Environmental Agency; Regional Personal Board; Community and Family Empowerment Board; and the Secretariat of Parliament of Depok City.

The data in this research is analyzed with emic and etic perspective, in order to produce a thorough description (thick description) and to find the meaning (verstehen). Qualitative approach is used for processing and analyzing data to understand the context of the data, so it can be more easily to understand and more meaningful to get the general pattern that emerges from it. In order to establish the validity of the data (trust worthiness), it is necessary to examine the data technique based on certain criteria.

\section{RESEARCH RESULT}

It should be emphasized that the administration in sustainable development ini Depok City in this research is a business or series of business efforts of growth and planned transformation which is done by the government of Depok City towards the modernity in order to educated the community to fulfill the needs of present generation without reducing the ability of future generation to fulfill their own needs. Therefore, the indicators of administration in sustainable development aspects consist of: 1. An effort or series of efforts of growth and planned transformation in Depok City. 2. Toward the modernization to educate in depok city. 3. Fulfill the needs of present and future generation in Depok City.

Each indicator is discussed deeply as follows.

1. An Effort or Series of Efforts of Growth and Planned Transformation in Sustainable Development in Depok City.

According to the result of the deep interview with the Key and Supporting informant indicates the sustainable development in Depok City is to create a fair and prosperous community based on Pancasila and UUD 1945 and guided by the longterm development year 2005-2025 for all of the citizen of Depok City at the present and in the future. It is affirmed that sustainable development is a development process characterized by the fulfillment of the needs of mankind, while 
observing and maintaining the quality of living environment. The endeavour is an effort or series of effort of growth and planned transformation in sustainable development, conducted by the government, the community, and the stake holders in Depok City.

The implementation of sustainable development in Depok City is conducted in order to reduce the development gap that occurred and to accelerate poverty countermeasure, and also to extend the work opportunity in Depok City. Among these activities, the development programs are rolled out. They are National Program of Community Self-Empowerment (Program National Pemberdayaan Masyarakat-PNPM Mandiri) through the Ministerial Decree of Coordinating Minister for People Wellfare as the Team Leader of Coordination of Poverty Reduction No:25/Kep/Menko/Kesra/Vii/2007 about PNPM Mandiri, and The Rural Infrastructure Development Program (Program Pembangunan Infrastruktur Pedesaan-PPIP) which is one of programs based on community empowering under PNPM Depok City.

Related to this, the result of FGD shows that these sustainable development programs has been conducted in every sub-district in Depok City. They are Beji sub-district; Pancoran Mas subdistrict; Cipayung sub-district; Sukmajaya subdistrict; Cilodong sub-district; Limo sub-district; Cinere sub-district; and Cimanggis sub-district. Therefore, the sustainable development is not only centered in Margonda Street and its impact can be felt by every citizen of Depok City.The direction of development in Depok City is now in the right track. It is becaused, according to Depok City Public Relations Division (2017), there is an increase in the value of Human Development Index (HDI) in Depok City. HDI is a government indicator to measure the success in buiding life quality of the community. It is also indicator of a succeed or a failure of the performance of the government of Depok City. Said indicator is also used to determine the ranking or the level of development in a region.

It is further explained that in 2015 HDI values of Depok City is 79,11. In 2016, the HDI of Depok City is increased to the level of 79,60 . The value of
HDI itself is on scale 0 to 100 . The HDI value above 80 is considered high. HDI in 66,0 to 79,9 is upper middle level, and the HDI value in 50 to 65,9 is categorized lower middle. HDI value less than 50 is assumed low. With the current HDI of 79.60, Depok City is cathegorized as upper midle in the development performance of the quality of the life of the community and the good performance of government. The result of the triangulation process can be stated that the context of HDI achievement is quite high in Depok, supported by several factors including the living hope of human in Depok City, reaching 74,01 per year. A quite high value of life expectancy in Depok City.

The achievement is related to sustainable development plan in Depok City that consists of main elements. The elements are the policies or basic strategy development plan, namely goals, directions, priorities, and targets of development. Several sustainable development policies in Depok City need to be arranged into short term and long term plan, and also for the technical programs and its implementation. In sustainable development context in Depok City, the development planning becomes important regarding to the economic sources which is now increasingly limited and will become exhausted, the large and diverse population, and the education level and management skill that have not yet optimal.

Civil Registry Office of Depok City recorded an increase of Depok residents to 47.133 people in 2016. The increase was dominated by migrants. The result of observation shows that the principals of regional development plan in Depok City is reffered to Government Regulation No. 8 Year 2008. It is further explained that the planning and budgeting of sustainable development in Depok City does not only refers to Law No. 17 Year 2003, but also refers to Law No. 32 Year 2004 which is also regulated by the Law No 25 Year 2004 on National Development Planning System (SPPN) and Law No. 17 Year 2003 on State Finances. Referring to the three Laws, the planning and budgeting in sustainable development in Depok City, especially in the term of the process, becomes the regional authority as outlined in the form of Local Regulation (Perda Kota Depok) No. 3 Year 2013 on Guidelines and Protection of 
Environmental Management) and refers to the Government Regulation of the Republic of Indonesia No. 46 Year 2016 on Procedures for the Implementation of Strategic Environmental Assessment.

The mechanism of sustainable development plan in Depok City, begins from the selection of aspiration from the community and the assessment of community needs through deliberation at village level followed by the deliberation at sub-district level and so on. Therefore, the sustainable development planning in Depok City is the main function of development administration which is always required. This said because the need for development is greater than the available resources. A good plan can formulate sustainable development activities effectively and efficiently. So, it will be able to obtain an optimal result in utilization the available resources and all of the potential that available in Depok City. In this discussion, the result of FGD shows that the sustainable development in Depok City is an effort or series of effort of growth and planned transformation which is done by the government of Depok City towards the modernity in order to meet the regional empowerment.

It is affirmed that the sustainable development in Depok City consists of three things. They are sustenance or the ability to fulfill the basic needs of the community, such as food, clothing, shelter, health, education, and saving money to survive; self esteem, the sustainable development in Depok City should be humanizing human. On a broad sense, the sustainable development in Depok City is to raise the pride as a human being (humanizing human), which means the exixtence of human being as resident or citizen of Depok City is being recognized by their existence; The last one is freedom from servitude, meaning a freedom for every citizen of Depok City to think, develop, behave, and strive to participate in sustainable development.

\section{Toward the Modernization to Educate in Depok City \\ Related to this discussion, the result of deep interview with the informants shows that the sustainable development in Depok City is not}

necessary to be related with the spatial aspects. The sustainable development that was formulated in Depok City through economic policies in many ways have proven its success, which is toward the modernity in Depok City. The economic policies in Depok City had been formulated conceptually by involving consideration of social aspects (sustainability) and supported by responsible political mechanism, so that every economic policy can be re-described transparently and fairly, and fulfilled the rules of regional plan.

In social aspect, not only the aspirations from citizen of Depok City that is considered, but also the social institution (social capital) is also maintained and even its function is improved. In the environmental aspect in Depok City, the function of natural capital sustainability is also needed to be observed for the benefit of present and future generation. Based on that things, it is important to be transparent in decision making from the various moral hazard, which is vested interest from rent seeking. Thus, the results of sustainable development in Depok City can be enjoyed by the whole community in a fair way through (inter-region) and inter-generation.

Therefore, the implication of spatial aspect study becomes less relevant in empirical condition as described above. However, the result of FGD shows that sustainable development in Depok City is in line with the development principles as implemented in other areas. It is also known that the implementation of sustainable development in Depok City have also weakness. The weakness emerges along the phenomenon in the community. They are the gap of economic and social problems, the poverty that is experienced by some of the citizen of Depok City, the inappropriate public management, the weakness of institutional mechanism, and unfair political system. These weaknesses are the obstacles in the field toward the community activities, goods and services, etc. with various risks to face either benefit or loss.

The result of triangulation shows that all the flows of economic and non-economic sources in Depok City become distorted, making a larger divergence. As a result, impact of sustainable development in Depok City can be easily found among sub-district, sectors, social group, or 
businessmen. Implicitly, there is a dichotomy over time as reflected in mistrust towards the sources in Depok City because of several risks (high inter temporal opportunity cost). This situation is not only far from moral values but also a reflection from destruction (in sustainability). This is not to mention the market mechanism that operates limitless.

The result of the observation shows that the condition in Depok City is somehow could not be prevented because it is still operating massively, continously, and acceptably by the economic logic as well as supported by economic policies sistematically. Moreover, the tendency of globalization and regionalization have brought together new challenges in sustainable development process in Depok City. Faced with these conditions, the conditions of competition among economic actors in Depok City will be sharper. In this sharp competittion condition, each economic doers has to apply and implement their business efficiently and effectively in its competitive strategy appropriately, which include a vision that can deal with any changes and interferences.

Furthermore, it should have a capability to maintain and develop a capacity in a manner that is flexible and quickly responsive towards any changes. As a buffer city of DKI Jakarta, Depok City is socio-culturally affected directly by the modernization of life. On the other hand, based on its community condition, Depok City is in all likelihood less prepared to receive the impact of modernization which can cause a complexity of social issues, such as: prostitution, delinquency of children and juvenile, etc.

\section{A Sustainable Development to Meet the Needs of Current and Future Generation}

In discussing the following indicator, we present findings from focus group discussion. It states that the ongoing sustainable development of Depok City is a development that meets the current community's need without having to reduce its capacity to fulfill the need of future generation. The ongoing sustainable development of Depok City has carefully taken into consideration the environmental utilization and sustainability so that environmental quality is still preserved. It is asserted that the unpreserved sustainable environment will definitely lead to a decreased environmental load capacity, or it may even cease to exist. The environmentally sustainable development has been Depok City government's policy; it is an endeavor to achieve a social justice from one generation to the next, i.e. a development that sustains a function and capability of the existing ecosystem.

The above condition is in line with findings from interviews with Key Informants and Supporting Informants, that a sustainable development in Depok City has reflected an effort capable of sustaining its natural environment. The said development has given the odds of survival, by means of preserving the function and capability of its supporting ecosystems both directly and indirectly. Furthermore, the ongoing development in Depok City has utilized its natural resources by harnessing eco-friendly technologies to provide opportunities to other sectors and activities to develop collectively in every sub-district, both simultaneously and on separate occasions sustainably, and also to improve and preserve the capability and function of ecosystem to supply, protect, and support the natural resources for life sustainably.

Likewise, the development in Depok City has adopted the procedure and practices that take into account the sustainability of ecosystem function and capacity to support the current and future living. The triangulation process further shows that the sustainable development policy by the government of Depok City has outlined its environment policy with regards to sustainable development, which include re-activating the growth. The said growth refers to an economic growth which is directly connected to public welfare. Indicators to determine public welfare may be identified based on per capita income.

Furthermore, in connection to the above indicator, findings from our observations show that the sustainable development in Depok City has changed the quality of life that is connected with the preservation endeavor of natural resources, improving income distribution, and resilience against various economic crises. Meeting of basic 
human needs, e.g. food, housing, clothing, energy, water and sanitation has to fulfill the minimum standard for people of the low income levels. Ensuring the achievement of sustainable population. The number of population capable of supporting the sustainable development refers to a stable population and in accordance with the resource capacity. High rate population growth (>2\% per annum) needs to be lowered to $0 \%$ population growth. Maintaining resource sustainability and increasing resources by way of creating and expanding employment, energy conservation and efficiency, prevention of pollution (both water and air) as early as possible.

The above development shall also conform towards technology and risk management, eg. creating and using an environmentally friendly technology innovation. Finally, the current development in Depok City has combined environmental and economic interests in its decision making. For example, the policy of energy utilization efficiency aims to produce the energy at minimum cost and with maximum utilization. Based on direct on the field observation and examination of Depok City, the execution of the above sustainable development needs an ecosystem approach by examining the interdependency of every ecosystem component. In order for the current and future development in Depok City to be sustainable, the local government directs its development at five points, namely: a development that takes into account a sustainable ecology.

The development in Depok City shall equally consider and pay attention to the existing ecology systems. It would be unwise if the said tremendous potential ecosystem and biodiversity are neglected, even destroyed, only for the sake of temporary sectoral development. Therefore, the environmental management and development implementation in Depok City must be carried out ecologically, because all materials in the environment are valuable resources. Adding another reason why ecological sustainability is necessary, is for Depok City's environment can be sustainable and passed down to the next generation in good condition, or at least no worse than the current condition in which the citizen of Depok
City receive and live in today, so that the next generation may still be able enjoy the same natural resources.

Next, the development of Depok City has considerably sought to create an economic sustainability. Within the said perspective, the economic development in Depok City has two main points, i.e.: a sectoral sustainable macro and micro economy. A sustainable macro economy means to ensure the economy in Depok City is sustainable and to encourage an economic efficiency through national and structural reformation. A sustainable sectoral economy may mean there is an economic value from managing resource in one sector, for example from industrialization of forestry or tourism, creating Depok as a Green City. For the sectoral economy in Depok City, the government is currently conducting efficiency in energy and resource utilization.

By observing the natural load capacity that tends to decline overtime, the sectoral and macro economic activities in Depok City shall not be of a short-term, but rather, it should be sustainable so that the revenue generated increases and continues to produce in the long run. The following is sustainable social-culture. Bhineka Tunggal Ika (Unity in Diversity) is a symbolic statement of Indonesian Nation which signifies a cultural diversity for Depok City. Depok City consists of people with its plurality and diversity, where most of its residents are migrants that come from all over Indonesia. Almost every ethnic has its own local custom or wisdom as a result of each natural adaptation. The cultural diversity in Depok City is evident and one form of regional assets. The life and existing values in such community, eg. hospitality, politeness, cooperation, etc., are among its social assets that need to be preserved in practicing a sustainable development.

\section{IV.DISCUSSION}

In this discussion, we present an interpretation of the findings and theories regarding the importance of existing and future researches. According to Brutland Report in UN assembly (1987), sustainable development is a development that refers to the principle of meeting the needs of 
the present without compromising the need of future generations. In order to achieve a sustainable development, one factor that must be dealt with is the way to rebuild the environmental destruction without sacrifising the need of economic and social justice development. The above notion is in accordance with a theory of sustainable development by Hadi (2007), that a sustainable development is a concept of development that aligns the interest of development with environmental management.

Further, the sustainable administrative development approach in this research is closely linked, related and influences each other's condition, political process development, economy, social and other development process. The above relations are contradictory, both in terms of neutral as well as corroborative relations. Administration of sustainable development provides the infrastructure and development movement in the field of public life. The opposite condition will influence the ability of administration development implementation, furthermore, the sustainable development administration also means the ability to respond to consequences in the process of the said sustainable development and improvement. Such administration of sustainable development moves within a fast development innovation (change), which often called "turbulence".

Subsequently, the sustainable development administration in Depok City is an endeavor or a series of development endeavors and a change of plan conducted by the government of Depok City, towards modernization in order for community building to meet the needs of current generation without reducing the ability of future generation to meet their needs. The sustainable development in Depok City may take place continuously and consistently, while maintaining the city and regional development, by not damaging the environment and taking into consideration the existing natural resource reserves for future needs. In order to implement the above sustainable development in Depok City, there is a need for a new paradigm in planning a city and regional development which conforms towards a market driven economy, social dimension, and environment and culture, acting as the current and future principles of justice

The sustainable development in Depok City is administered in a planned way by the Government of Depok City, the public/community, as well as other stakeholders. A condition cannot be stated as sustainable when the existing natural capital is used or even damaged massively, when compared to the rate of its recovery. So as with Depok City, the environmental damage due to human greediness is not only endured by the local community, but also jeopardize the life of mankind globally, and what's even more dangerous, is its impact towards humankind in the future. The environmental pollution in Depok City is caused by, among others, degradation of air quality, which is created by tremendous congestion in almost every area of Depok City.

In addition, the air pollution is also caused by Hazardous and Poisonous Materials or commonly known as B3, namely material or other components that may endanger the health or survival of human, other creatures, and or environment in general. Due to its nature, the said hazardous and poisonous components and its waste need a special treatment. Depok City is currently building its infrastructure quite rapidly, with the support from Depok City government revenue of IDR 2.67 trillions. Consequently, its effort to actively improve itself has attracted a lot of property developers. An easy and accessible connection to reach Jakarta via commuter line, Trans Jakarta, as well as Cinere-Jagorawi and Depok-Antasari highway is adding the value of the region.

The property development of both housing and commercial within Depok City region is very fast, owing to the high market uptake. The attractiveness of Depok City for property developers is due to the potentiality of highway infrastructures, such as: Cinere-Jagorawi (Cijago) and Depok-Antasari (Desari). Both highways are predicted to boost the property development in Depok City. The existence of the said highways, whose construction is underway, has successfully increased the market value of the local land about $20 \%$ annually (source: PR of Depok Regional Gov., 2016). The highways have increased the land value in the region quite high, in particular the areas in Margonda Street, Juanda Street, and its surrounding areas. 
Accordingly, the development of the said areas must be vertical. The above description shows that, theoretically, a study on "Sustainable Development Administration" is an important aspect that needs to be examined for the future, because it is closely linked with a sustainable life.

\section{CONCLUSION}

In the following conclusion, we restate the research question and findings briefly, and we review the implications of the current research findings. The main question in this research serves as 'problem formulation', i.e.: how is the sustainable development administration in Depok City? This study finds that a sustainable development administration in Depok City has been formulated in both short term and long term planning, and the objective is to create a just and prosperous society according to Pancasila and UUD 1945, and based on the National Long Term Planning 2005-2025 for all current and future residents in Depok City.

The sustainable development in Depok City requires a strong commitment from its government administrators in formulating, executing and evaluating its development policies. Furthermore, in supporting the sustainable development in Depok City, the administration execution has been quite selective and efficient, taking into account the environmental aspects in all policies and within democratic development framework. The sustainable development administration in Depok City is a development process characterized with fulfilling the needs of current and future community, while taking into account and maintainingthe balance between natural environment (biological and non-biological natural resources) and constructed environment (human and artificial resources), so that the interaction and inter-dependency between the two remains in equal harmony.

The above endeavor is an effort or a series of growth and change endeavors in a planned way in developing sustainably, both by the government, public/community as well as stakeholders in Depok City. Implementation of sustainable development in Depok City is in pursuance of reducing the current development gap, accelerating poverty alleviation, and expanding of employment opportunities, while maintaining the existing the sustainability of ecosystems. The said development has been planned and taken into consideration the increasingly limited and depleting economic resources, the vast number of population and its diversity, as well as the level of education and managerial capability that is yet optimal.

Further, the said development is consistently based on the principles of regional development planning in Depok City. Implication of existing research findings is that economic development in Depok City was initially only measured bythe Human Development Index (HDI). In 2015 the HDI of Depok City was at 79.11 and in 2016 the $\underline{\text { HDI }}$ of Depok City has increase to 79.60 . The higher the HDI of a region, the better is the economic development in the region. The above notion will encourage every region (including Depok City) to increase its HDI number by exploiting its existing natural resource and increasing industrialization.

The pursuit of undertaken economic growth generally demands vast amount of revenues and within a short period of time. Examples of such acts include massive illegal logging, transportation that damages the environment, and other acts including other exploitations that can increase overall revenues as well as per capita. Furthermore, the development of industrialization sector may also create a serious impact on the environment, such as factory waste, air pollution, and effect of global warming. Therefore, a development system is required which not only prioritizes the current economic development, but also takes into consideration meeting the needs in the future (sustainable economic development by preserving the natural resources). The sustainable development shall not only concentrate on environmental issues, but more than that, it must encompass the three developmental policies, i.e.: economy, social development, and environmental production.

\section{REFERENCES}


Cresswell, John W. 2002. Research Design.

Quantitative \& Qualitative Approaches, New York: Sage Publication, Inc.

Effendi, H., 2003. Telaah Kualitas Air Bagi Pengelolaan Sumber Daya dan Lingkungan Perairan. Kanisius, Jakarta.

Eko, I. W., S. Anong, 1996. Karakteristik beban pencemaran limbah penduduk di Bandung dan Yogyakarta. Bulletin Pus Air, Media Kegiatan Penelitian Keairan 5(21), pp. 1535.

Fadly, N. A., 2008. Daya tampung dan daya dukung Sungai Ciliwung serta strategi pengelolaannya. Thesis. Program Studi Teknik Sipil, Program Pascasarjana Bidang Ilmu Teknik, Universitas Indonesia, Depok.

Moleong, J. Lexy, 2006. Metodologi Penelitian Kualitatif, 22nd Edition, Bandung: $\mathrm{Pt}$ Remaja Rosdakarya. 